\title{
Wood supply challenges in Alberta - Growing more timber is the only sustainable solution
}

\author{
by Bradley D. Pinno ${ }^{1 *}$, Barb R. Thomas ${ }^{1}$ and Victor J. Lieffers ${ }^{1}$
}

\begin{abstract}
The industrial wood supply from public lands is at risk in Alberta from natural disturbances and landbase withdrawals while simultaneously being asked to provide for an increasing timber harvest rate. While maintaining the timber landbase is critical, we believe that the only truly sustainable way of increasing wood supply is by growing more wood. Meeting these wood supply goals will require the application of tree improvement and intensive silviculture programs on the best sites to increase timber productivity, reduce rotation lengths, and close timber supply gaps. In this article, we present the main ideas from a recent Canadian Institute of Forestry - Rocky Mountain Section workshop on wood supply in Alberta and provide what we see as the best path forward to meeting our wood supply goals - growing more timber.
\end{abstract}

Keywords: wood supply, silviculture, tree improvement, timber productivity

\section{RÉSUMÉ}

Dans les forêts publiques de l'Alberta l'approvisionnement en bois pour l'industrie est menacé par les perturbations naturelles et la diminution de la surface productive alors qu'on escompte une augmentation de la production de bois. Bien qu'il soit essentiel de stabiliser la surface productive, nous prétendons que la seule façon d'accroître l'approvisionnement en bois est de produire plus de bois. Pour atteindre ces objectifs de production ligneuse, il faudra miser sur l'application de programmes d'amélioration des arbres et de sylviculture intensive sur les sites les plus fertiles en vue d'accroître la production de bois, de diminuer les rotations et de combler les écarts dans l'approvisionnement en bois. Dans cet article, nous exposons les principales idées qui ont émané d'un atelier de la section Rocky Mountains de l'Institut forestier du Canada sur l'approvisionnement en bois en Alberta et présentons ce qui nous semble la voie d'avenir pour atteindre nos objectifs de production ligneuse: faire pousser plus de bois.

Mots-clés: approvisionnement en bois, sylviculture, amélioration des arbres, production ligneuse

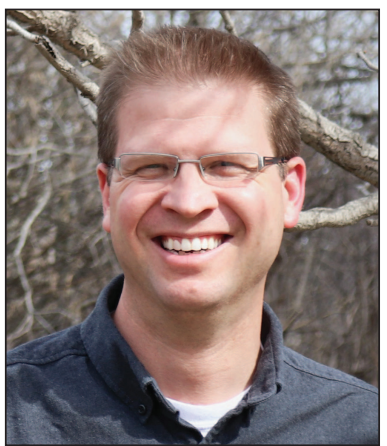

Bradley D. Pinno

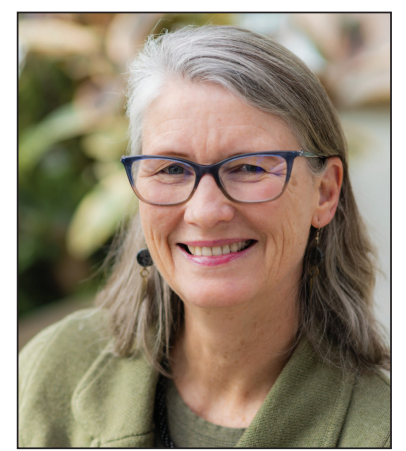

Barb R. Thomas

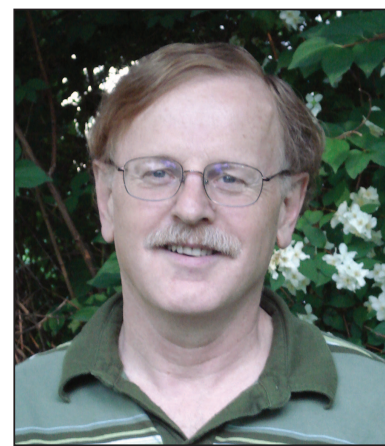

Victor J. Lieffers

annual allowable cut (AAC) has been reduced from approximately $60 \mathrm{M} \mathrm{m}^{3}$ to $40 \mathrm{M} \mathrm{m}^{3}$ due to the effects of the mountain pine beetle outbreak, large fires, and landbase withdrawals resulting in $52 \%$ of land being outside of the active timber management zone (Mycock 2020). A similar wood supply crunch with a reduction in AAC is emerging in Alberta, or at least in some management units, and requires a change in forest man-

\section{The Challenges}

A consistent wood supply is a key component of sustainable forest management, however, wood supply is at risk in many locations given the increase in natural disturbances, such as fire, insects and drought, and a shrinking forestry landbase, including lands withdrawn into protected areas, thereby reducing the area contributing to the sustainable harvest level. For example, in the interior of British Columbia, the agement to curb the impact of these losses. Interestingly, the Alberta Minister of Agriculture and Forestry has recently stated a desire to not just maintain harvesting levels but to increase AAC and timber harvesting on public lands by up to $13 \%$ to expand the viability of the forest industry (Government of Alberta 2020). These may seem like contradictory notions, but we believe that there are a range of options available to Alberta forest managers to avoid a timber supply

${ }^{1}$ Department of Renewable Resources, University of Alberta, 442 Earth Sciences Building, Edmonton, Alberta, T6G 2E3 ${ }^{\star}$ Correspondence: bpinno@ualberta.ca 
reduction and perhaps increase sustainable harvest levels through a focus on increasing the growth of forests and managing the risks of disturbance across the landscape. Given this context, the Canadian Institute of Forestry - Rocky Mountain Section recently organized a virtual workshop on November 19, 2020 on wood supply (http://www.cif-ifc. org/gp_sections/rocky-mountain/) that brought together foresters from industry, consulting companies, environmental groups, government, student groups, and academia to discuss the issue of wood supply in Alberta. The goal of this article is to highlight some of these discussions and help facilitate the changes in forest management that will be required to meet these wood supply objectives.

At its most basic, sustainable wood supply is a function of the land area producing timber and the rate of timber production of this land. The current AAC in Alberta from provincially managed public forest lands is $19.6 \mathrm{M} \mathrm{m}^{3}$ of conifer and $12.8 \mathrm{M} \mathrm{m}^{3}$ of deciduous timber (Alberta Agriculture and Forestry 2017). The conifer AAC has been continually increasing for over a decade, likely due to forest management practices increasing the growth rate of post-harvest stands. One of the main wood supply concerns, however, is the continual reduction of the landbase contributing to sustainable timber production due to expanding infrastructure for industrial developments and static biodiversity reserves and protected areas. Although the area-based Forest Management Agreement (FMA) tenure system in Alberta is viewed as being successful in securing this timber producing landbase, there are still continued reductions in the productive landbase for other uses (Winship 2020). Developing a system of dynamic biodiversity reserves, potentially including some provincial park land, watercourse buffers, and other reserve areas that still allow for some timber extraction, is seen by many as one possible way of maintaining or increasing the land area contributing to our fibre supply. It is unclear how much timber volume this approach could realistically and sustainably produce but it is certain that any proposal for harvesting timber in these currently reserved areas would require silvicultural practices other than the classic clearcut and plantation model commonly used for conifers. Management in these currently protected areas would likely require some combination of partial harvesting and extended rotations but would only be socially acceptable if it aligns with the ecological goals and integrity of these lands.

Increased harvesting of unallocated timber outside of current FMA areas is another way to increase timber harvest. Currently, there is roughly $1.3 \mathrm{M} \mathrm{m}^{3} \mathrm{AAC}$ of unallocated conifer timber and $1.0 \mathrm{M} \mathrm{m}^{3} \mathrm{AAC}$ of deciduous timber in Alberta (Alberta Agriculture and Forestry 2017). However, the majority of this unallocated timber is located in remote northern areas and in socially and/or ecologically sensitive areas such as important recreational areas near cities or national parks. Harvesting in these areas may be unacceptable for either economic or social reasons. In addition, these areas are already included in provincial AAC calculations and so would not contribute to an increased provincial AAC simply by approving increased harvest levels within them.

Standing mature timber is increasingly being lost to fire (McLaughlin 2020) and insect outbreaks (Goodsman 2020), and along with drought, these disturbances are only expected to increase in time with climate change (Brecka et al. 2018).
While the areas impacted by these disturbances can be partially salvaged for timber, the increasing frequency of these disturbances implores forest managers to implement practices that will reduce these risks (Lieffers et al. 2020). Options include favouring more fire-resistant species on the landscape, growing mixed species forests to reduce severity of insect attack, and density management to reduce fuel loads and increase drought tolerance of remaining trees. Tree breeding for resiliency traits along with increased timber yields on shorter rotations is also possible and could be combined with more aggressive reforestation programs in these naturally disturbed areas. But for this to happen, public investments after disturbance will be required as timber companies are only responsible for reforesting areas that they harvest.

\section{Possible Solutions}

While all of these options will contribute to securing the fibre supply on the timber producing landbase, we believe that the best approach for sustainably increasing that supply in Alberta is by growing timber faster through the planting of genetically improved seedlings coupled with intensive silvicultural practices. The best results will be achieved on the most productive sites and this intensive management must be balanced with areas of extensive management and conservation. Tree improvement (TI) programs are a major investment for both industry and government in Alberta. Yield gains tend to be perceived as low but in reality, the potential gains are much higher (Thomas 2020). For example, improved white spruce seedlings have shown a $4.4 \%$ increase in height growth over wild collected seedlings which corresponds to a volume increase of approximately 9\%; gains for lodgepole pine are just slightly below this. However, these yield gains are not currently being fully recognized in timber supply calculations in Alberta (Schreiber and Thomas 2017). An increasing amount of white spruce planted in Alberta is from seed orchards but a doubling of orchards is needed to meet this growing demand for improved seedlings with higher growth potential. Advanced breeding strategies including genomic selection are also shortening breeding timelines substantially such that yield gains are expected to increase even further in the near future (see https://resfor.ualberta.ca/ for more details). It is clear that tree improvement has a major role to play in the future wood supply in Alberta but in order to realize these potential gains operationally, appropriate silviculture must be applied to protect this investment.

Intensive silviculture in Alberta has great potential as it is the most productive boreal forest in Canada due to the rich, fine-textured soils with a high water and nutrient holding capacity. Experience from other parts of the world indicates that we could expect a 3-4 x yield increase over natural forests so that mean annual increments (MAI) of $8+\mathrm{m}^{3} /$ ha/year are likely with rotation ages of 50 years (Pinno 2020) compared to the current productivity of natural forests with a MAI in the $2-4 \mathrm{~m}^{3} / \mathrm{ha} /$ year range. Achieving this productivity rate, however, will involve more intensive plantation management of conifers with site preparation and planting of improved seedlings, followed by competition control. Density management, in particular commercial thinning in plantations and pre-commercial thinning in naturally regenerated stands, will also need to become a common silviculture 
treatment. Currently, it seems that thinning is viewed as an unproven tool that must be linked with incremental and onerous monitoring programs that create a barrier to its use. Intensive management of mixedwood stands are also possible depending on the timber management goals (Man et al. 2008) and these mixed species forests could be an optimal choice for maximizing timber growth while minimizing risks. The requirement to maintain their pre-harvest species composition in most stands, however, limits management options (Lieffers et al. 2020).

Unbalanced age-class distributions and the requirement for non-declining, even-flow yields are major constraints on the AAC in most management units in Alberta (Held 2020). These constraints, however, can be alleviated through the application of tree improvement and silvicultural techniques that reduce time to merchantability, thereby closing the timber supply gaps. In addition, the costs associated with these increased silvicultural investments are generally not as high as most foresters perceive (Winship 2020). A primary incentive to grow timber faster on public land is the Allowable Cut Effect (ACE), with the right to harvest more mature timber now, if regenerating stands grow faster than previous stands (Luckert and Haley 1995). However, the full effect of ACE is rarely applied in Alberta given the substantial risk of natural disturbances and the lack of mature growing stock in many regions. Therefore, the evaluation of silviculture and tree improvement programs should include direct links to the local timber supply constraints, normally long regulated rotation lengths and unbalanced age-class distributions, rather than simply through the ACE potential.

Growing more timber is the only truly sustainable way to increase timber supply and harvest levels in Alberta and this will require a shift in thinking among everyone in the forestry community, from being focused on timber harvesting of wild stands, to being focused on timber growing. Canada has nearly $10 \%$ of the world's forest lands and a sustainable wood supply should be recognized as a social, economic and ecological priority to sustain forest dependent communities (Parkins 2020) and to supply timber products with a low carbon footprint to Canada and beyond.

\section{Acknowledgements}

We thank the organizers, presenters, and participants in the Canadian Institute of Forestry - Rocky Mountain Section workshop on wood supply. The thoughtful ideas, comments, and discussion that came out of the event shaped this paper.

\section{Workshop References}

(Based on order of presentation) from the workshop, Timber supply in Alberta's forests - these are risky times, held virtually on November 19, 2020 by the Canadian Institute of Forestry - Rocky Mountain Section. All presentations are available online at: http://www.cif-ifc.org/gp_sections/rocky-mountain/ Mycock, J. 2020. Decades of timber supply hindsight - if we knew then what we know now. Jeff Mycock is Chief Forester, West Fraser.
Winship, R. 2020. Wood supply: Perspectives on the big picture. Bob Winship is Strategic Team Coordinator, Weyerhaeuser Pembina.

Held, B. 2020. Alberta timber supply analysis - lessons learned. Bob Held is a retired resource analyst.

Parkins, J. 2020. Sustaining timber, sustaining rural communities: Shared destiny or separate paths? John Parkins is a Professor in the Department of Resource Economics and Environmental Sociology, University of Alberta.

McLoughlin, N. 2020. Landscapes on fire. Neal McLoughlin is Wildfire Management Unit Lead, Provincial FireSmart Program, Alberta Agriculture and Forestry.

Thomas, B. 2020. What role can tree improvement play in meeting our fibre needs? Barb Thomas is a Professor in the Department of Renewable Resources, University of Alberta.

Goodsman, D. 2020. Why understanding insect dispersal matters for managing forests threatened by tree-killing insects. Devin Goodsman is an Entomologist, Canadian Forest Service, Natural Resources Canada.

Pinno, B. 2020. Opportunities for increasing timber supply in Alberta through intensive silviculture. Brad Pinno is an Assistant Professor, Department of Renewable Resources, University of Alberta.

\section{Other References}

Alberta Agriculture and Forestry (AAF). 2017. Sustainable Forest Management: 2016 Facts \& Statistics, Annual Allowable Cut. Published spring 2017. Accessed on November 20, 2020 from https://open.alberta.ca/dataset/a5b5f0fd-a4f1410d-8a39-1df024a217fc/resource/a4ae3411-47a2-4dd292b5-93953d3eaaf5/download/af-forest-managment-stats2016-annual-allowable-cut.pdf

Brecka, A.F.J., C. Shahi and H.Y.H. Chen. 2018. Climate change impacts on boreal forest timber supply. For. Pol. Econ. 92:11-21.

Government of Alberta. 2020. Forest jobs action plan: A commitment to sustainable, long-term fibre access for forest companies. Published May 2020. Accessed on November 20, 2020 from https://open.alberta.ca/dataset/92a98c62-94944806-9a99-27838024a02a/resource/40125b04-cf43-4589ade8-d9b5674d24dc/download/af-forest-jobs-action-plan2020-05.pdf

Lieffers, V.J., B.D. Pinno, J.L. Beverly, B.R. Thomas and C. Nock. 2020. Reforestation policy has constrained options for managing risks on public forests. Can. J. For. Res. 50:855861.

Luckert, M.K. and D. Haley. 1995. The allowable cut effect as a policy instrument in Canadian forestry. Can. J. For. Res. 25:1821-1829.

Man, C.D., P.G. Comeau and D.G. Pitt. 2008. Competitive effects of woody and herbaceious vegetation in a young boreal mixedwood stand. Can. J. For. Res. 38:1817-1828.

Schreiber, S.G. and B.R. Thomas. 2017. Forest industry investment in tree improvement - a wise business decision or a bottomless pit? Answers from a new tree improvement valuation model for Alberta, Canada. For. Chron. 93: 38-43. 